\title{
Nursing students' experience of academic learning in a Cambodian School of Nursing
}

Andrea Ryan ${ }^{1}$, Kem Sokunthea, Chhouk Borey, Leam Lin, Ek Samol, Im Saron, Thann Sreymom, Tineke Water

\section{Abstract}

The purpose of the study was to determine nursing students' satisfaction of their experiences of their academic program at a university nursing school in Cambodia. Positive experiences of educational programs have been linked to the increased development of a professional identity and beliefs around the chosen discipline. As nursing education and the nursing profession continues to undergo rapid development and change in Cambodia, it was seen that an evaluation of both the teaching quality and nursing students' experience within a program of study was an important aspect of maintaining high quality nursing education programs. The study is a cross-sectional design using the Undergraduate Nursing Students' Academic Satisfaction Scale (UNSASS) in addition to demographic data. The UNSASS, with permission from the authors, underwent a cross-cultural adaptation for the Cambodian context. Analysis was undertaken using SPSS version 17.0. One hundred and seventy Associate Degree and Bachelor of Science in Nursing students were surveyed, including students in their middle and final years of study from both cohorts. The findings show that overall students felt positively about their education experience, felt safe to make mistakes in a supportive environment, and had positive relationships with the faculty and clinical preceptors. However, the large number of neutral responses may indicate a cultural hesitance in reporting any negative feedback.

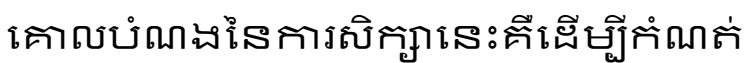

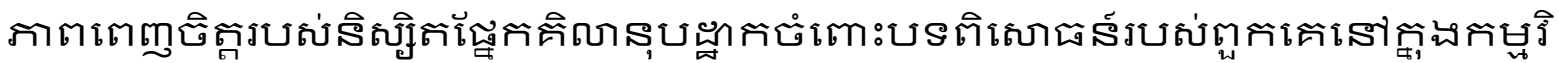

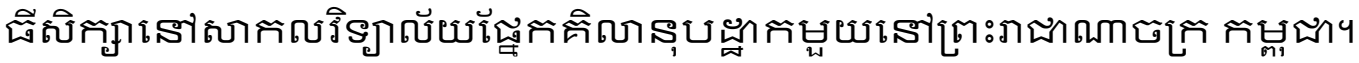

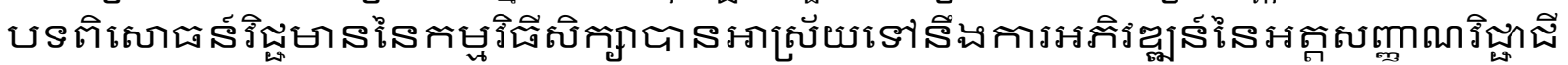

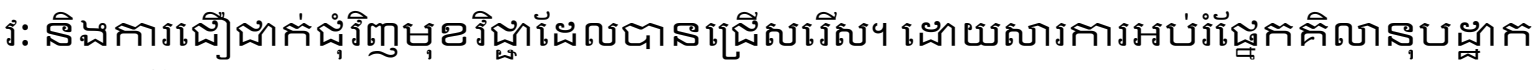

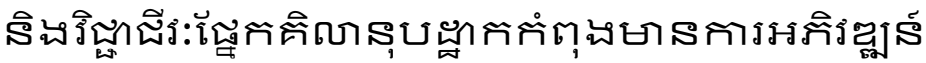

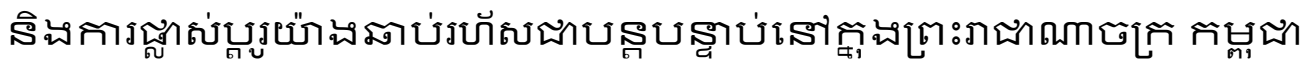

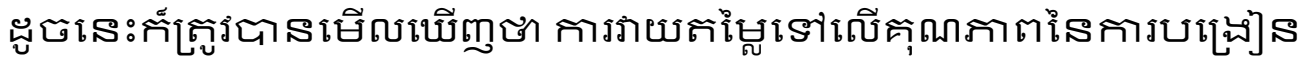

\footnotetext{
${ }^{1}$ Andrea Ryan is the corresponding author ryanandreab@gmail.com
} 


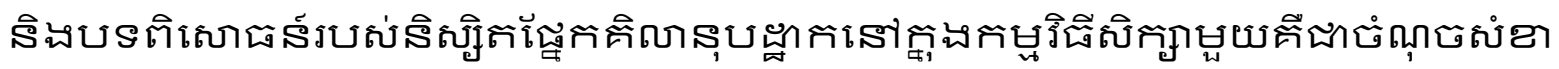

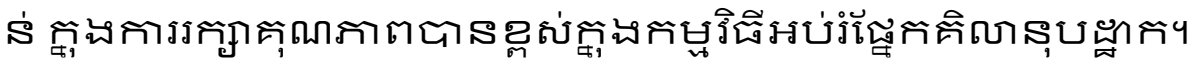

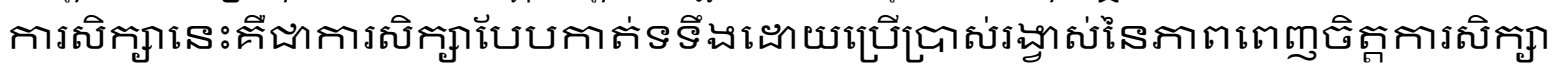

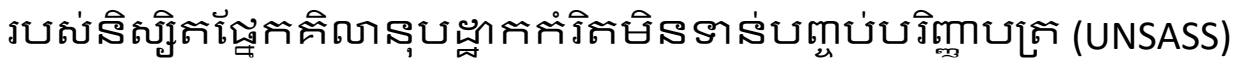

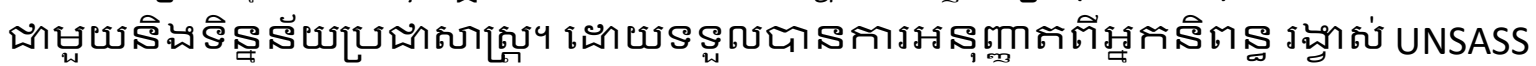

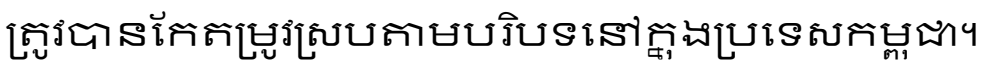

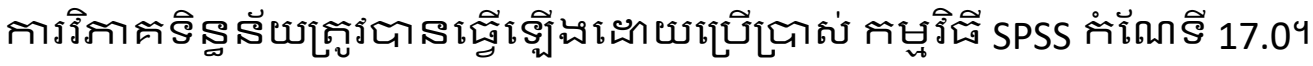

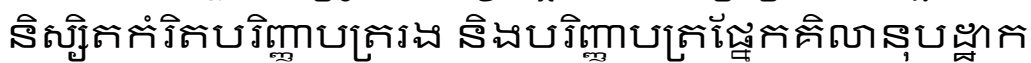

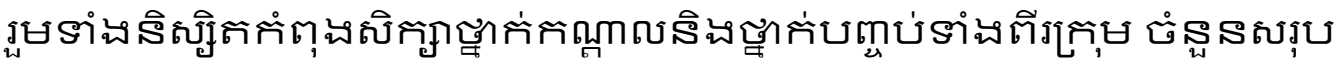

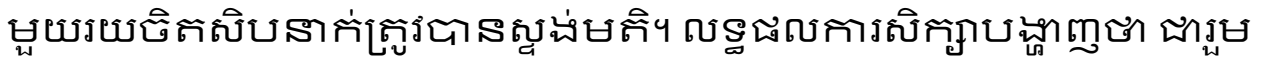

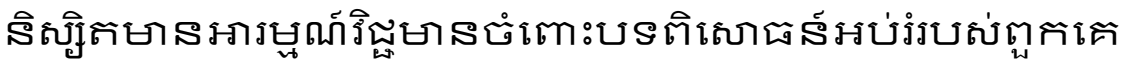

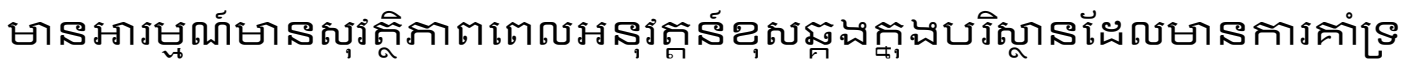

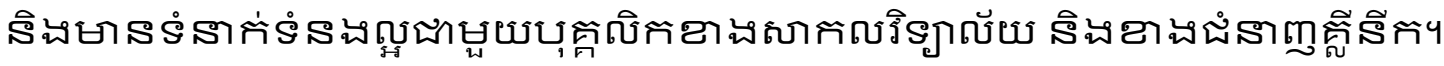

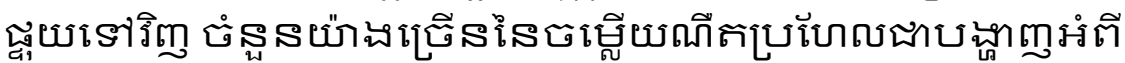

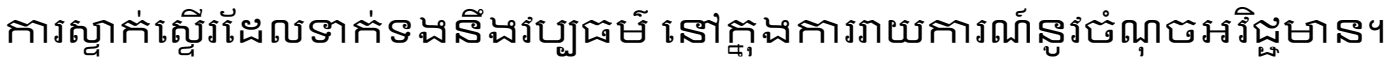

Key words: Cambodia, nursing, education, students 


\section{Introduction}

The purpose of the study was to determine nursing students' satisfaction of their experiences of their academic program at a university nursing school in Cambodia. Positive experiences of educational programs have been linked to the increased development of a professional identity and beliefs around the chosen discipline. As nursing education and the nursing profession continues to undergo rapid development and change in Cambodia, it was seen that an evaluation of both the teaching quality and nursing students' experience within a program of study was an important aspect of maintaining high quality nursing education programs.

\section{The history of nursing education in Cambodia.}

Nursing education in Cambodia was established in 1950 with just one nursing school providing a 2-year General Nursing Course (Koy, 2016). In 1960, this was extended to a 3-year Diploma program (Western Pacific Region Nursing and Midwifery Databank, Cambodia, 2013). Civil war and unrest from 1975 onwards, following the rise and fall of the Khmer Rouge regime, deeply impacted the infrastructure of Cambodian society, education, and health (Koy, 2016). The deaths of teachers and health professionals between 1975 and 1979 during the Khmer Rouge regime resulted in an accumulated loss of knowledge, expertise and, in turn, lack of health service delivery (Koy, 2016). After the collapse of the Khmer Rouge regime, the new government prioritized the building of infrastructure including nursing education, and a 1-year Primary Nurse program was established in 1979 followed by a 3-year Secondary program for nurses (Western Pacific Region Nursing and Midwifery Databank, Cambodia, 2013).

By 1996 there were 5 government nursing schools, and in 2002 the first private school of nursing was approved by the $\mathrm{MOH}$ (Cambodian Council of Nurses, 2017). Currently, there are 6 public and 12 private schools of nursing in Cambodia offering two pathways to becoming a registered nurse: a 3-year Associate Degree in Nursing (ADN); and a 4-year Bachelor of Science in Nursing degree (BSN). There is a 2-year Bachelor of Science in Nursing Bridging degree (BSNB) for Associate Degree nurses to upgrade to a Bachelor's degree. In addition, there continues to be a bridging program for primary nurses who have undergone a 1-year training to upgrade to ADN. Most of the 
nursing workforce have an associate degree qualification, with an estimated 750 nurses with a Bachelor's degree in 2017 (Cambodian Council of Nurses, 2017).

Koy (2016) provides the significant milestones in the history of nursing in Cambodia (see table 1).

Table 1

\begin{tabular}{|l|}
\hline Year Description of education \\
\hline 1950: First Nursing School founded, and a 2-year General Nursing Course commenced. \\
\hline 1960: Nursing course was expanded to be a 3-year diploma program. \\
\hline 1975: Nursing school closed by Khmer Rouge regime. \\
\hline 1979: 1-year Primary Nurse and Primary Midwifery course commenced. \\
\hline 1980: 3-year Secondary Nurse and Secondary Midwifery program commenced. \\
\hline 1983: 2-year bridging program for Primary Nurses to Secondary Nurses commenced. \\
\hline 1989: 1-year Primary Nurse and Primary Midwifery program phased out. \\
\hline 1991: 2-year Anaesthesiology and 1-year Dental Nursing course was commenced. \\
\hline 1994: New curriculum for 3-year Secondary Nurse and Secondary Midwife commenced. \\
\hline 1995: 3+1-year Secondary Nurse Midwifery curriculum introduced \\
\hline 1997: 2-year bridging course from Primary to Secondary Nurse and Primary to Secondary \\
Midwife commenced. \\
\hline 1998: Nursing curriculum revised for Secondary Nursing program and a 1-year program of \\
Basic Eye Nurse course commenced. \\
\hline 1999: 1.5-year Psychiatric/Mental Health Nursing course commenced and 2- year \\
Anaesthesiology course phased out. \\
\hline 2003: 1-year program for Nurse Manager commenced. \\
\hline 2006: 1-year program for Nurse Manager phased out. \\
\hline 2007: Curriculum revised for Secondary Nurse/Associate Degree in Nursing. \\
\hline 2008: 4-year Bachelor of Science in Nursing program commenced. \\
\hline 2013: 2-year bridging course from ADN to BSN commenced. \\
\hline
\end{tabular}

A significant influence on nursing education in Cambodia in recent times has been the establishment of the ASEAN Economic Community in promoting a single economic market. The Mutual Recognition Arrangements (MRA) on Nursing Services (2006) aims to increase mobility of nursing profession services across the region, with a focus 
on standards, qualifications, and best practices. However, in an analysis of the issues faced by each of the 10 ASEAN member countries in achieving high quality health services, it was identified that the lack of educationally prepared nursing faculty and the dominance of doctor-led nursing education were two major barriers to high quality nursing education in Cambodia (Koy, 2016). Therefore, improving nursing education is seen equally as important as increasing numbers in the workforce to the overall quality improvement of a healthcare system (Koto-Shimada, Yanagisawa, Boonyanurak \& Fujita, 2016).

\section{Evaluating nursing students' experience}

In November 2007, the University of Puthisastra was established as a private, accredited Higher Education Institute (HEI). In October 2011, the first Health Science students were enrolled, including nursing students. Currently, the Department of Nursing at the University of Puthisastra offers the Associate Degree in Nursing (ADN) program, the Bachelor of Science in Nursing (BSN) program and the Bachelor of Science in Nursing Bridging program (BSNB). The first cohort of graduates from the ADN was November 2014, from the BSN program in November 2015, and the first cohort of students from the BSNB program, graduated in November 2020.

It was important to gather information from the first graduating cohorts to gain their perceptions of the quality of the program, as students' evaluation of the teaching quality and their experience within a program of study is seen as a significant aspect of any quality management in higher education (AI Rubaish, 2010). The information gained can be used to identify areas of strength and areas for development within a teaching faculty, helping develop recommendations, strategies, or practices for quality improvement. From a student perspective, the relationship between a positive course experience and a student's approach to learning has repeatedly demonstrated that students' satisfaction of their academic environment is associated with deeper learning. Student evaluation of programs does have a direct influence on their academic outcomes (Yin, Lu \& Wang, 2014).

Students' perceptions, learning satisfaction and their developing professional identity is linked to the quality of the teaching faculty, including teacher competencies and, in turn, the quality of the programs offered (Behnampour, 2012; Long, Ibrahim, \& Kowang, 2014). Students' satisfaction of their learning environment also shapes their 
beliefs around their chosen profession (Chou \& Liu, 2005; El Ansari \& Oskrochi, 2006; Yang, Becerik-Gerber \& Mino, 2013). Positive views of learning have been correlated with positive views of their field of study (Rejali et al., 2010; Sanaei Nasab et al., 2010).

Quality assurance evaluation in Cambodian HEls has focused on student evaluation of teaching quality. Student evaluation of teaching quality gathers information from a student's perspective of teacher's knowledge, skills, and professional attitude. Teacher characteristics are often used to measure effectiveness and quality of teaching including, for example, punctuality, professional appearance, and ability to explain clearly (Zerihun, Beishuizen \& van Os, 2012). However, little is known about how students' experience teaching programs within HEls settings in Cambodia.

The objective of teaching is student learning. If students are to be encouraged to engage actively in their own learning, they must also have a say in how they experience this. Students' experience of their learning will influence motivation, selfefficacy and, ultimately, how ready they are to enter their profession (Hassankhani, Aghdam, Rahmani \& Mohammad, 2016). Therefore, understanding the experiences of students within a nursing program is useful in examining the likely continuing impact of the teaching as they move into their profession. The aim of this study was to determine nursing students' satisfaction of their experiences of an academic nursing program.

\section{Study design}

The design for this study was cross-sectional, using a validated survey that was culturally adapted and simple for participants to use. This design was chosen as it was suitable for the subset of the student population who were the specific participants to be surveyed. While cause and effect cannot always be described in a cross-sectional study design, a range of variables were analysed. The UNSASS validated survey using a 5-point Likert scale was used. A cross-cultural adaptation process using back translation with different translators was undertaken to ensure appropriateness for the Cambodian context. Demographic data was collected in addition to the UNSASS. Analysis was undertaken to classify variables collected in the survey using SPSS version 17.0. 


\section{Methods}

Potential participants included $n=324^{\text {th }}$ year BSN students and $n=1383^{\text {rd }}$ year ADN students. Potential participants were sent a participant information sheet explaining the study a week prior to the survey being administered, through their class representative. Student involvement is seen as one way to guarantee against manipulation or coercion in the process of recruitment (CHERI, n.d). The participant information sheet emphasized the voluntary nature of participation in responding to the survey. On a set day, two researchers administered the paper based anonymous UNSASS survey 15 minutes before the end of an ADN and BSN class. The researchers were not these students class teachers; however, they were teachers in the Nursing Department. If teachers were to be completely removed from the process, the survey may be seen as no more than a management tool, of no direct benefit to students and thus adversely impact the response rate. The researchers explained the parameters of the study again: its purpose; that the survey was anonymous and voluntary; and that if students did not want to participate, they could return a blank survey. Participants were given 15 minutes to complete the survey, and the surveys were then hand-collected. One hundred and seventy completed surveys were returned. This represents a $100 \%$ return rate - not usual in most surveys. Possible explanations include the cultural context, where participants are more likely to agree to participate even when they are unsure. The research team had discussed that administering an online survey may have supported a context where students would have felt more comfortable choosing not to complete the survey, however very few students have access to a laptop or desktop computer at home. Response rates are substantially higher when faculty provide in-class, face-to-face surveys to students, as was done in this study (Young, Jones, Standish \& Gallagher, 2019). Data entry was carried out by two researchers, who cross-checked for accuracy. SPPS was used to generate descriptive statistics in percentages.

The survey process is one that is familiar to all students in Higher Education (HE) in Cambodia. It is considered best practice across the universities to undertake course level evaluation at the end of every semester. It was made clear to students this survey was different in that it was a program level survey. Students were sent the participant information sheet prior to the survey being administered and it was discussed with their class representative - a peer and colleague. 


\section{Demographic data}

Just over half of participants were female (56\%) and $44 \%$ were male, representative of the gender mix in the Cambodia nursing workforce. Seventy percent $(70 \%)$ of students were aged between 21-23 years, which reflects an entry age into a career of 19-21 years. This is the norm in Cambodia as students' complete high school around the age of 18 years. Most of the participants were Buddhists, which is also representative of the general population in Cambodia. Most students were single (95\%). Most students did not undertake paid work (88\%), although $37 \%$ of students did engage in volunteer work. Half of the students spoke two languages or more $(50.3 \%)$.

Table 2 Demographic data

\begin{tabular}{|c|c|c|c|}
\hline Demographics & & $\mathrm{N}=$ & $\%$ \\
\hline \multirow[t]{2}{*}{ Sex } & Female & 94 & 55.95 \\
\hline & Male & 74 & 44.05 \\
\hline \multirow[t]{5}{*}{ Age Group } & $18-20$ & 37 & 21.76 \\
\hline & $21-23$ & 119 & 70.00 \\
\hline & $24-26$ & 12 & 7.06 \\
\hline & $27-29$ & 1 & 0.59 \\
\hline & $30-35$ & 1 & 0.59 \\
\hline \multirow[t]{3}{*}{ Religion } & Buddhism & 155 & 92.26 \\
\hline & Islam & 5 & 2.98 \\
\hline & Others & 8 & 4.76 \\
\hline \multirow[t]{2}{*}{ Marital status } & Married & 8 & 4.71 \\
\hline & Unmarried & 162 & 95.29 \\
\hline \multirow[t]{2}{*}{ Part time job } & No & 149 & 88.17 \\
\hline & Yes & 20 & 11.83 \\
\hline \multirow[t]{2}{*}{ Volunteer work } & No & 104 & 63.03 \\
\hline & Yes & 61 & 36.97 \\
\hline \multirow[t]{4}{*}{ Languages } & 1 & 63 & 49.61 \\
\hline & 2 & 60 & 47.24 \\
\hline & 3 & 3 & 2.36 \\
\hline & 4 & 1 & 0.79 \\
\hline
\end{tabular}

\section{Classroom teaching}

Almost three quarters of the students (73.7\%) felt that they were able to express any concerns to the academic lecturers, and that the lecturers were approachable (84\%), 
were readily available after class $(80 \%)$, were fair to students $(67.6 \%)$ and there to help students $(70 \%)$. Although a high percentage of students identified that academic lecturers were approachable and accessible, there was less confidence that the lecturers would always understand student difficulties (62\%). Over half of the students stated they would know where to go if they had a complaint or any concerns $(57 \%)$ however over one third (34.1\%) of students indicated a neutral response.

Most students felt that academic lecturers helped motivate them (84\%). Students also felt academic lecturers were knowledgeable about their course area $(79.3 \%)$ and that they were given enough time to understand the things they had learnt (68.9\%). A high percentage of students identified that they received adequate feedback from academic lecturers $(79.3 \%)$, with two thirds of students $(67 \%)$ stating that this feedback was detailed.

Table 3 Classroom teaching

\begin{tabular}{|c|c|c|c|c|c|c|c|c|c|c|c|c|}
\hline \multirow[t]{2}{*}{ Question } & \multicolumn{2}{|c|}{$\begin{array}{l}\text { Strongly } \\
\text { Agree }\end{array}$} & \multicolumn{2}{|c|}{ Agree } & \multicolumn{2}{|c|}{ Neutral } & \multicolumn{2}{|c|}{ Disagree } & \multicolumn{2}{|c|}{$\begin{array}{l}\text { Strongly } \\
\text { Disagree }\end{array}$} & \multicolumn{2}{|c|}{$\begin{array}{l}\text { No } \\
\text { response }\end{array}$} \\
\hline & $\mathrm{N}$ & $\%$ & $\mathrm{~N}$ & $\%$ & $\mathrm{~N}$ & $\%$ & $\mathrm{~N}$ & $\%$ & $\mathrm{~N}$ & $\%$ & $\mathrm{~N}$ & $\%$ \\
\hline $\begin{array}{l}\text { I can freely express my } \\
\text { concerns to lecturers }\end{array}$ & 29 & 17.2 & 95 & 56.5 & 40 & 23.8 & 4 & $\begin{array}{l}2.3 \\
8 \\
\end{array}$ & & & 2 & 1.1 \\
\hline $\begin{array}{l}\text { Lecturers are } \\
\text { approachable }\end{array}$ & 44 & 25.8 & 99 & 58.2 & 27 & 15.8 & & & & & & \\
\hline $\begin{array}{l}\text { Lecturers help students } \\
\text { who are having difficulties }\end{array}$ & 38 & 22.3 & 68 & 40.0 & 52 & 30.5 & 10 & 5.8 & 1 & 0.5 & 1 & 0.5 \\
\hline $\begin{array}{l}\text { Lecturers make } \\
\text { themselves available for } \\
\text { questions after class }\end{array}$ & 55 & 32.3 & 82 & 48.2 & 30 & 17.6 & 3 & 1.7 & & & & \\
\hline $\begin{array}{l}\text { I can freely express my } \\
\text { concerns to non-nursing } \\
\text { departments }\end{array}$ & 21 & 12.5 & 60 & 35.7 & 70 & 41.6 & 10 & 5.8 & & & 9 & 5.2 \\
\hline $\begin{array}{l}\text { Lecturers are fair and } \\
\text { unbiased towards } \\
\text { students }\end{array}$ & 42 & 24.7 & 73 & 42.9 & 42 & 24.7 & 9 & 5.2 & 4 & 2.3 & & \\
\hline $\begin{array}{l}\text { Lecturers give students } \\
\text { good feedback on their } \\
\text { progress }\end{array}$ & 31 & 18.2 & 104 & 61.1 & 28 & 16.4 & 7 & 4.1 & & & & \\
\hline $\begin{array}{l}\text { I received detailed } \\
\text { feedback from lecturers } \\
\text { on all my course work }\end{array}$ & 29 & 17.0 & 85 & 50.0 & 54 & 31.7 & 1 & .59 & 1 & 0.5 & & \\
\hline $\begin{array}{l}\text { Students know who to go } \\
\text { if they have complaints }\end{array}$ & 11 & 6.47 & 86 & 50.5 & 58 & 34.1 & 14 & 8.2 & 1 & 0.5 & & \\
\hline $\begin{array}{l}\text { Lecturers are good role } \\
\text { models and motivate me } \\
\text { to do my best }\end{array}$ & 48 & 28.2 & 95 & 55.8 & 24 & 14.1 & 3 & 1.7 & & & & \\
\hline
\end{tabular}




\begin{tabular}{|l|l|l|l|l|l|l|l|l|l|l|l|l|}
\hline $\begin{array}{l}\text { Administration shows } \\
\text { concern for students }\end{array}$ & 21 & 12.3 & 87 & 51.1 & 52 & 30.5 & 8 & 4.7 & 2 & 1.1 & & \\
\hline $\begin{array}{l}\text { Lecturers demonstrate a } \\
\text { high level of knowledge in } \\
\text { their subject }\end{array}$ & 40 & 23.5 & 95 & 55.8 & 29 & 17.0 & 4 & 2.3 & 2 & 1.1 & & \\
\hline $\begin{array}{l}\text { Lecturers take time to } \\
\text { listen to students about } \\
\text { academic issues }\end{array}$ & 21 & 12.3 & 104 & 61.1 & 36 & 21.1 & 7 & 4.1 & 2 & 1.1 & & \\
\hline $\begin{array}{l}\text { Lecturers create an overall } \\
\text { good impression }\end{array}$ & 26 & 15.3 & 90 & 53.0 & 45 & 26.6 & 7 & 4.1 & 1 & 0.5 & 1 & 0.5 \\
\hline $\begin{array}{l}\text { I am given enough time to } \\
\text { understand the things I } \\
\text { have to learn }\end{array}$ & 19 & 11.1 & 98 & 57.6 & 44 & 25.8 & 9 & 5.2 & & & & \\
\hline
\end{tabular}

\section{Technical practice and practicum}

Most students reported that the technical practice lecturers were approachable (87.4\%), were open to discussing skills theory and procedures $(83.9 \%)$, and that they were given sufficient guidance before performing a procedure (86.5\%). Most students reported positively on the learning environment stating that technical practice lecturers helped them learn from their mistakes (85\%) and would provide feedback at an appropriate time and in a way that would not embarrass them in front of other students (84\%). Students reported that technical practice lecturers help them develop critical thinking skills in their nursing practice (83.3\%), and supported students to link theory and practice (84.6\%). Technical practice lecturers were perceived as knowledgeable (78.6\%), and good role models for professional behaviour (81.1\%).

There appeared to be a good fit between what was taught in the classroom and what was practiced in the clinical environment (85.2\%). Most students felt well-prepared to go into the clinical environment (65\%), felt supported by preceptors in the clinical environment and were able to improve their clinical skills through adequate feedback (70.3\%) and clinical teaching by the preceptors (72.7\%). However, there was less agreement on the preceptors' availability for the students in the clinical environment (57.5\%). 
Table 4 Technical practice and practicum

\begin{tabular}{|c|c|c|c|c|c|c|c|c|c|c|c|c|}
\hline & \multicolumn{2}{|c|}{$\begin{array}{l}\text { Strongly } \\
\text { Agree }\end{array}$} & \multicolumn{2}{|c|}{ Agree } & \multicolumn{2}{|c|}{ Neutral } & \multicolumn{2}{|c|}{ Disagree } & \multicolumn{2}{|c|}{$\begin{array}{l}\text { Strongly } \\
\text { Agree }\end{array}$} & \multicolumn{2}{|c|}{$\begin{array}{l}\text { No } \\
\text { response }\end{array}$} \\
\hline & $\mathrm{N}$ & $\%$ & $\mathrm{~N}$ & $\%$ & $\mathrm{~N}$ & $\%$ & $\mathrm{~N}$ & $\%$ & $\mathrm{~N}$ & $\%$ & $\mathrm{~N}$ & $\%$ \\
\hline $\begin{array}{l}\text { TP lecturers are } \\
\text { approachable, and } \\
\text { students can ask } \\
\text { questions }\end{array}$ & 51 & 30.1 & 97 & 57.4 & 19 & 11.2 & 2 & 1.1 & & & 1 & 0.5 \\
\hline $\begin{array}{l}\text { TP lecturers provide } \\
\text { feedback at } \\
\text { appropriate times and } \\
\text { do not embarrass me } \\
\text { in class }\end{array}$ & 33 & 19.5 & 109 & 64.5 & 24 & 14.2 & 2 & 1.1 & 1 & 0.5 & 1 & 0.5 \\
\hline $\begin{array}{l}\text { TP lecturers are open } \\
\text { to discussion of } \\
\text { procedures }\end{array}$ & 39 & 23.0 & 103 & 60.9 & 24 & 14.2 & 3 & 1.7 & & & 1 & 0.5 \\
\hline $\begin{array}{l}\text { TP lecturers give me } \\
\text { sufficient guidance } \\
\text { before I perform a } \\
\text { procedure }\end{array}$ & 52 & 30.7 & 95 & 55.8 & 21 & 12.4 & 1 & 0.5 & & & 1 & 0.5 \\
\hline $\begin{array}{l}\text { TP lecturers help me } \\
\text { learn from my } \\
\text { mistakes }\end{array}$ & 46 & 27.3 & 97 & 57.7 & 24 & 14.2 & 1 & 0.5 & & & 2 & 1.1 \\
\hline $\begin{array}{l}\text { Nursing staff give me } \\
\text { clear information of } \\
\text { what is expected } \\
\text { when going to } \\
\text { practicum }\end{array}$ & 17 & 10.6 & 92 & 54.4 & 52 & 30.7 & 6 & 3.5 & & 3 & & \\
\hline $\begin{array}{l}\text { TP lecturers help me } \\
\text { develop critical } \\
\text { thinking skills in my } \\
\text { nursing practice }\end{array}$ & 28 & 16.5 & 113 & 66.8 & 25 & 14.7 & 3 & 1.7 & & & & \\
\hline $\begin{array}{l}\text { Preceptors teach me } \\
\text { about patient care } \\
\text { and nursing process } \\
\text { when I am in } \\
\text { practicum }\end{array}$ & 22 & 13.0 & 101 & 59.7 & 35 & 20.7 & 7 & $\begin{array}{l}4.1 \\
4\end{array}$ & 4 & $\begin{array}{l}2.3 \\
7\end{array}$ & & \\
\hline $\begin{array}{l}\text { I get adequate } \\
\text { feedback to improve } \\
\text { my skills when I am in } \\
\text { practicum }\end{array}$ & 25 & 14.7 & 94 & 55.6 & 43 & 25.4 & 6 & $\begin{array}{l}3.5 \\
5\end{array}$ & 1 & 0.5 & & \\
\hline
\end{tabular}




\begin{tabular}{|l|l|l|l|l|l|l|l|l|l|l|l|l|}
\hline $\begin{array}{l}\text { TP lecturers } \\
\text { demonstrate a high } \\
\text { level of knowledge }\end{array}$ & 39 & 23.0 & 94 & 55.6 & 35 & 20.5 & 1 & 0.5 & & & & \\
\hline $\begin{array}{l}\text { Preceptors are } \\
\text { generally available for } \\
\text { students in practicum }\end{array}$ & 19 & 11.1 & 79 & 46.4 & 58 & 34.7 & 8 & $\begin{array}{l}4.7 \\
9\end{array}$ & 3 & 1.8 & & \\
\hline $\begin{array}{l}\text { Nursing staff provide } \\
\text { enough opportunities } \\
\text { for self-practice in the } \\
\text { lab }\end{array}$ & 19 & 11.1 & 102 & 60.0 & 38 & 22.3 & 9 & 5.2 & 2 & 1.1 & & \\
\hline $\begin{array}{l}\text { TP lecturers } \\
\text { encourage me to link } \\
\text { theory to practice }\end{array}$ & 46 & 27.0 & 98 & 57.6 & 24 & 14.1 & 2 & 1.1 & & & & \\
\hline $\begin{array}{l}\text { TP lecturers teach } \\
\text { procedures the same } \\
\text { as practiced in } \\
\text { practicum }\end{array}$ & 49 & 28.8 & 96 & 56.4 & 20 & 11.7 & 4 & 2.3 & 1 & 0.5 & & \\
\hline $\begin{array}{l}\text { TP lecturers and staff } \\
\text { behave professionally }\end{array}$ & 32 & 18.8 & 106 & 62.3 & 31 & 18.2 & 1 & 0.5 & & & \\
\hline
\end{tabular}

\section{Nursing program design and delivery}

Most students reported that the nursing program provided a variety of relevant and good courses $(77.6 \%)$ that were beneficial to their development towards becoming a nurse $(88.1 \%)$. However, many students identified that there were additional courses that should be included (83.4\%). As these additional topics were neither listed nor identified this should be followed up in future surveys. Students reported positively that the nursing program supported learning how to work in a team (82.3\%), helped them to develop problem solving and decision-making skills (79.3\%), and assisted with confidence in resolving clinical nursing problems $(77 \%)$. The overall quality of teaching was reported as good and helpful (81.7\%), the expectations of the program were clear $(79.9 \%)$, and the requirements of the program were reasonable and achievable $(75.8 \%)$. One area that fell below the expected standard was the expectation that program would help students improve their English. Although $45.7 \%$ responded positively there was a remarkably high neutral score (41.7\%). 
Table 5 Nursing program design and delivery

\begin{tabular}{|c|c|c|c|c|c|c|c|c|c|c|}
\hline & \multicolumn{2}{|c|}{$\begin{array}{l}\text { Strongly } \\
\text { Agree }\end{array}$} & \multicolumn{2}{|c|}{ Agree } & \multicolumn{2}{|c|}{ Neutral } & \multicolumn{2}{|c|}{ Disagree } & \multicolumn{2}{|c|}{$\begin{array}{l}\text { Strongly } \\
\text { Disagree }\end{array}$} \\
\hline & $\mathrm{N}=$ & $\%$ & $\mathrm{~N}=$ & $\%$ & $N=$ & $\%$ & $\mathrm{~N}=$ & $\%$ & $\mathrm{~N}=$ & $\%$ \\
\hline $\begin{array}{l}\text { The nursing program } \\
\text { provides a variety of } \\
\text { good and relevant } \\
\text { courses }\end{array}$ & 22 & 12.94 & 110 & 64.7 & 34 & 20.0 & 4 & 2.35 & & \\
\hline $\begin{array}{l}\text { There are some } \\
\text { important additional } \\
\text { subjects that should } \\
\text { be included in the } \\
\text { nursing program }\end{array}$ & 44 & 25.8 & 98 & 57.6 & 24 & 14.1 & 3 & 1.76 & 1 & 0.5 \\
\hline $\begin{array}{l}\text { Most courses in the } \\
\text { nursing program are } \\
\text { beneficial for my } \\
\text { overall nursing } \\
\text { development }\end{array}$ & 46 & 27.0 & 104 & 61.1 & 17 & 10 & 2 & 1.1 & 1 & 0.5 \\
\hline $\begin{array}{l}\text { The quality of } \\
\text { teaching I received in } \\
\text { class is good and } \\
\text { helpful }\end{array}$ & 34 & 20.0 & 105 & 61.7 & 28 & 16.4 & 2 & 1.1 & 1 & 0.5 \\
\hline $\begin{array}{l}\text { I usually have a clear } \\
\text { idea of what is } \\
\text { expected of me in } \\
\text { the nursing program }\end{array}$ & 19 & 11.1 & 117 & 68.8 & 32 & 18.8 & 2 & 1.1 & & \\
\hline $\begin{array}{l}\text { The nursing program } \\
\text { helps students learn } \\
\text { teamwork }\end{array}$ & 23 & 13.53 & 117 & 68.8 & 24 & 14.2 & 5 & 2.94 & 1 & 0.5 \\
\hline $\begin{array}{l}\text { The nursing program } \\
\text { help my problem } \\
\text { solving and decision- } \\
\text { making skills }\end{array}$ & 31 & 18.2 & 104 & 61.1 & 32 & 18.8 & 3 & 1.76 & & \\
\hline $\begin{array}{l}\text { There is a } \\
\text { commitment to } \\
\text { academic quality in } \\
\text { the nursing program }\end{array}$ & 20 & 11.76 & 102 & 60.0 & 46 & 27.0 & 2 & 1.18 & & \\
\hline $\begin{array}{l}\text { As a result of my } \\
\text { courses, I feel } \\
\text { confident in dealing } \\
\text { with clinical nursing } \\
\text { programs }\end{array}$ & 21 & 12.3 & 110 & 64.7 & 34 & 20.0 & 5 & 2.94 & & \\
\hline
\end{tabular}




\begin{tabular}{|l|l|l|l|l|l|l|l|l|l|l|}
\hline $\begin{array}{l}\text { Going to class helps } \\
\text { me understand the } \\
\text { course }\end{array}$ & 19 & 11.8 & 116 & 68.2 & 33 & 19.4 & 2 & 1.18 & & \\
\hline $\begin{array}{l}\text { I can improve my } \\
\text { English in this nursing } \\
\text { program }\end{array}$ & 9 & 5.2 & 69 & 40.5 & 71 & 41.7 & 17 & 10 & 4 & 2.35 \\
\hline $\begin{array}{l}\text { Overall, the nursing } \\
\text { program } \\
\text { requirements are } \\
\text { reasonable and } \\
\text { achievable }\end{array}$ & 20 & 11.7 & 109 & 64.1 & 35 & 20.5 & 6 & 3.35 & & \\
\hline
\end{tabular}

\section{Support and resources}

Overall, students reported satisfaction with the processes for enrolment, class, and exams (62.8\%). Sixty-eight percent $(68.1 \%)$ of students also either agreed or strongly agreed that the laboratory and computer areas were well equipped. However, 31\% either remained neutral or disagreed. Near seventy percent $(69.9 \%)$ of students did report that these areas helped their learning. Just over half of the students reported other departments were caring and helpful to students (51\%).

Table 6 Support and resources

\begin{tabular}{|l|l|l|l|l|l|l|l|l|l|l|}
\hline & \multicolumn{3}{l}{\begin{tabular}{l}
\multicolumn{2}{l}{ Strongly } \\
agree
\end{tabular}} & \multicolumn{2}{l|}{ Agree } & \multicolumn{2}{l|}{ Neutral } & \multicolumn{2}{l|}{ Disagree } & \multicolumn{2}{l|}{$\begin{array}{l}\text { Strongly } \\
\text { disagree }\end{array}$} \\
\cline { 2 - 11 } & $\mathrm{N}=$ & $\%$ & $\mathrm{~N}=$ & $\%$ & $\mathrm{~N}=$ & $\%$ & $\mathrm{~N}=$ & $\%$ & $\mathrm{~N}=$ & $\%$ \\
\hline $\begin{array}{l}\text { Other departments } \\
\text { are caring and helpful } \\
\text { to students }\end{array}$ & 14 & 8.2 & 74 & 43.5 & 70 & 41.1 & 12 & 7.0 & & \\
\hline $\begin{array}{l}\text { Processes for } \\
\text { enrolment, class and } \\
\text { exams are easy for } \\
\text { students }\end{array}$ & 18 & 10.5 & 89 & 52.3 & 55 & 32.3 & 7 & 4.1 & 1 & 0.5 \\
\hline $\begin{array}{l}\text { Labs and computer } \\
\text { areas are well } \\
\text { equipped }\end{array}$ & 19 & 11.1 & 97 & 57.0 & 43 & 25.2 & 10 & 5.8 & 1 & 0.5 \\
\hline $\begin{array}{l}\text { The classrooms and } \\
\text { labs environment help } \\
\text { my learning }\end{array}$ & 26 & 15.2 & 93 & 54.7 & 41 & 24.1 & 6 & 3.5 & 4 & 2.3 \\
\hline
\end{tabular}

\section{Discussion}

Overall, the findings were positive with only one question, 'I can improve my English', scoring over $50 \%$ for neutral or disagree. While half of the students spoke two or more 
languages $(50.3 \%)$ only $45.7 \%$ responded positively to the fact that the program helped them to improve their English. There was a remarkably high neutral response $(41.7 \%)$ to this question. English has since been introduced as a core course in the University and is well embedded across all health science faculties.

The two questions (6 and 44) related to 'other non-nursing departments' scored high on disagree/strongly disagree $(52.8 \%$ and $48.1 \%$ respectively). It may be these questions were not clearly worded, as there was no distinction made between faculty and supporting departments. However, it could also reflect a low level of interdisciplinary integration between students across different faculty due to minimal formal opportunity for this to take place. Gurayaa and Barr (2018) discuss that where there are interdisciplinary learning activities, there is a positive effect on students' knowledge, skills, and attitudes. Students in subsequent programs have been provided these opportunities to enhance their learning through interdisciplinary activities such as shared community outreach programs (missions), and to enhance collegiality through social and sporting activities run by the University.

All other questions scored over $50 \%$ on agree/strongly agree around positive aspects of the program. Although there was positive scoring overall, there was a high rate of neutral scoring which was linked to a higher corresponding disagree/strongly disagree score. Neutral scores with a survey can be problematic, as there is no way of knowing what this might mean (i.e., more positive, negative, do not know, not sure, or do not want to say). It is argued that using a 7-point Likert item survey is less likely to result in extremes of response. However, labelling of the points on the scale can also impact on responses. Labelling all points can lower extreme response because of the preference for the neutral options and positive answers, regardless of what question is being asked (Krosnick, 1991). In Khmer culture, it is not polite to disagree so therefore students may have reported 'neutral' rather than a negative disagree/strongly disagree response.

Students reported that they could talk to the lecturers about most things, which was significant in the finding that they felt they could make mistakes and not feel embarrassed. Making errors or mistakes is a significant issue for nursing students and health professionals. Students in a nursing program are judged on their performance, which includes key competencies. Although critical reflection on practice is one of the 
required competencies, the focus is also on clinical safety. Nurses and nursing students have a moral and legal duty of care to maintain safe clinical practice but, equally, there are occasions where errors do happen. The idea that a mistake is a result of a performance failure fails to acknowledge other factors such as systems, organizations, lack of training or support and environmental conditions (Clancy, Effken \& Pesut, 2008; IOM, 2000). The response to a mistake may be punitive (such as receiving a 'Fail' grade in a clinical placement/rotation), which can result in a reluctance to disclose the mistake, a loss in confidence, and lack of transparency, where more supportive actions could have been implemented to prevent future errors. The concept of "saving face" in South East Asia can also contribute to a reluctance to disclose errors (Theam, 2015) however, in this study, this may have been offset by informal communication pathways both in the University setting and the clinical setting being an enabler for students to be able to report any mistakes (Espin \& Meikle, 2014). Making mistakes is an important matter for students (in any health care profession) as mistakes are learning opportunities. But how the mistake is responded to and addressed by the faculty or clinical area can either be supportive or traumatic for the student (Zieber \& Williams, 2015).

A high percentage of students (84\%) felt that lecturers motivated them throughout their program, which has been shown to be an important factor in students' learning experience (Jeong et al., 2018). While students reported positive channels of communication with lecturers, they also stated they were not always sure that lecturers would understand their problems. This could be due to cultural expectations that lecturers may be reluctant to ask further questions or ask for clarification of issues (Theam, 2015), a generational divide where students feel their issues would not be understood by the lecturers (Hart, 2017), or a difference in expectations between students and lecturers of the lecturer role or academic program (Hassel \& Ridout, 2017). Recently, the Nursing Faculty introduced a pastoral care program, overseen by faculty staff and linked to health and counselling services within the University, to provide nursing students with mechanisms for academic and personal support.

In the literature, there is much discussion on the 'theory-practice gap' in low and high resources settings, with common themes including restricted opportunities to practice clinical skills and decision making; lack of resources in university laboratories or clinical settings; lack of clinical supervision by faculty, clinical lecturers, or staff; and 
lack of consistency across institutions (Salifu, Gross, Salifu \& Ninnoni, 2019; Odetola et al., 2020; Huston et al., 2018). Students in this study, reported a good fit between theory and practice reflecting what Ewertsson et al, (2015) refer to as 'walking the bridge', whereby there is a transfer of knowledge and skills to practice using reflective practice, laboratory teaching environments and clinical practice opportunities. In Cambodia, most nursing lecturers teaching in university nursing programs also work in hospital environments, which means they can integrate and encourage students to reflect on examples from everyday practice. The Ministry of Health also oversees the provision of nursing education in Cambodia, leading to a standardized curriculum across the sector. In addition, the University has clinical instructors who are also nursing lecturers, who go out to hospital settings when students are in practicum and liaise with preceptors who have multiple responsibilities in the workplace. Kermansaravi, Navidian, and Yaghoubinia (2015) argue that two significant strategies to overcome the theory-practice gap is the standardization of nursing education and having nursing academic lecturers who also work in clinical roles.

Students stated they wanted additional topics taught. However, what these topics were, or their scope, was not assessed because of the nature of the questionnaire (closed questions). In Cambodia, the $\mathrm{MOH}$ sets a minimum nursing curriculum, but student feedback suggested they wanted more than just the minimum topics. In more recent times, extra courses have been added such as English, basic statistics (scaffolding for research), computer skills, and critical thinking.

Just over sixty-two percent (62.8\%) of students were satisfied with the enrolment processes and exam processes, although 32.3\% remained neutral. This is seen as an area for improvement, and since this survey was carried out there have been changes implemented. The academic year has become more structured with students having a scheduled study week prior to one week of theory exams and one week of clinical exams. An Academic Examination Board process has also been implemented to ensure fair assessment processes for all students. Online enrolment processes have also been introduced recently which may enhance the enrolment process for students.

In the area of technical practice laboratories and computer laboratories, nearly one third $(31.5 \%)$ of students did not agree that they were well-resourced. This includes 
$25.2 \%$ of participants who remained neutral. There has been a focus on updating computer labs in recent times with laboratory equipment noted for future requisition to align with the $\mathrm{MOH}$ curriculum revision. This is an important issue, as lack of resourcing of practice labs has been identified in other studies and contributes to an increase theory-practice gap (Salifu, Gross, Salifu \& Ninnoni, 2019; Odetola et al., 2020; Huston et al., 2018).

In summary, although there was an overall positive scoring in the survey responses, there was also a high rate of neutral scoring, particularly in support and resources for nursing students. Updating of simulation equipment will be aligned with the national review of nursing curricula. Nationally, the $\mathrm{MOH}$ is driving the revision of nursing education curricula, transitioning to contemporary, best practice competency-based education so it may be useful to further survey students to clarify where they feel a specific need for improvement in resources would best be focused. However, many changes have been implemented in the nursing program at the University since the completion of the survey, such as introduction of English as a core course, a pastoral care program, and improvement in academic processes.

\section{Limitations}

Although cross-cultural adaption is important to ensure cultural appropriateness and context-specific congruence, there is always the possibility of words and meanings being lost in translation. Khmer is a complex language, and one where, at times, there is no direct/close translation of the English equivalent. As the survey responses were closed (on a Likert scale), there is less possibility for ambiguity across questions/responses. However, the researchers remain aware of the potential issues regarding what may have been lost in translation.

One of the limitations of using a closed question survey is that there is no opportunity to follow up on further lines of questioning that could give a deeper or broader understanding of the topic. For example, although students reported that the nursing program provided a variety of courses that supported their learning, they also indicated that additional courses should be included. There is no way of knowing, from this survey, what these courses are which may have been useful in any revision of program content. 
Using an existing, validated questionnaire can help the reliability of a study. However, caution needs to be taken as the questions may not be context specific. For example, in the questionnaire there were two questions related to students' interactions with 'non-nursing' departments. These questions scored high on disagree/strongly disagree regarding students' confidence in contacting other departments for support when there was no formal opportunity for this to happen.

In addition, while technical practice teaching was a focus, equipment and resources in technical practice laboratories were not separated out from computer laboratories. Students were not asked about their experience of using the simulation equipment available to them. This is also an important point as experience in simulation laboratories may also decrease the theory-practice gap.

\section{Conclusion}

Evaluation of nursing education programs has traditionally focused on students' feedback of the lecturers' teaching rather than the students' experiences of their nursing program. Students' perceptions and satisfaction of their program of study, as well as their developing professional identity, is linked to the quality of the nursing program in which they are enrolled. As there continues to be a rapid change to nursing education and the nursing profession in Cambodia, influenced by the need to meet regional expectations, standards, and regulation of nursing services, the continued improvement in nursing education is a priority in the overall improvement of quality of health care delivery in Cambodia.

Acknowledgements: Eng Muyngim for providing the translation into Khmer for the abstract. 
References

Abedin, N., Taib, J., \& Jamil, H. (2014). Comparative study on course evaluation process: students and lecturers' perceptions. Procedia - Social and Behavioral Sciences, 20, 380-388. https://doi.org/10.1016/j.sbspro.2014.01.1436

Ajani, K., \& Moez, S. (2011). The gap between knowledge and practice in nursing Procedia Social and Behavioural Science, 15, 3927-393.

Al Rubaish, A. (2010). On the contribution of student experience survey regarding quality management in higher education: An institutional study in Saudi Arabia. Journal of Service Science and Management, 3, 464-9. https://doi.org/10.4236/jssm.2010.34052

ASEAN Joint Coordinating Committee on Nursing. Retrieved on the $19^{\text {th }}$ of September 2020 from:

https://asean.org/asean-economic-community/sectoral-bodies-under-the-purview-ofaem/services/healthcare-services/nursing-services-ajccn/

Behnampour, N., Heshmati, H., \& Rahimi, S. (2012). A survey on paramedical and health stduents with their discipline and some related factors. IJME, 12(8), 616-18.

Cambodia Council of Nurses

$\underline{\text { http://cambodiancouncilofnurse.com/different-education-paths-adn-bsn/ }}$

Centre for Higher Education Research and Information (CHERI) (n.d.). Collecting and using student feedback on quality and standards of learning and teaching in HE. A report to HEFCE. NOP Research Group and SQW Ltd. https://dera.ioe.ac.uk/4988/1/rd08 03.pdf

Chou, S., \& Liu, C. (2005). Learning effectiveness in a web-based virtual learning environment: A learner-controlled perspective. Journal of Computer Assisted Learning, 12, 65-76.

Clancy, T. R., Effken, J. A., \& Pesut, D. (2008). Applications of complex systems theory in nursing education, research, and practice. Nursing Outlook, 56(5), 248-256. 
Dennison, S., \& El-Masri, M. (2012). Development and psychometric assessment of the undergraduate nursing students' academic satisfaction scale (UNSASS). Journal of Nursing Management, 20(2),75-89.

El Ansari, W., \& Oskrochi, R. (2006). What matters most? Predictors of student satisfaction in public health educational courses. Public Health, 120(5), 462-73

Espin, S., \& Meikle, D. (2014). Fourth-Year Nursing Student Perceptions of Incidents and Incident Reporting. Journal of Nursing Education, 5(4) Doi:10.3928/0148483420140217-04

Ewertsson, M., Allyin, R., Holmstrom, I., \& Blomberg, K. (2015) Walking the bridge: Nursing students' learning in clinical skill laboratories. Nurse Education in Practice, 15(4). DOI: 10.1016/i.nepr.2015.03.006

Gurayaa, S., \& Barr, H. (2018). The effectiveness of interprofessional education in healthcare: A systematic review and meta-analysis; Kaohsiung Journal of Medical Sciences, 34, 160-165.

Hart, S. (2017). Today's learners and educators: Bridging the generational gaps. Teaching and Learning in Nursing, 12(4), 253-257.

Hassankhani, H., Aghdam, A., Rahmani, A., \& Mohammadpoorfard, Z., (2016). The Relationship between Learning Motivation and Self Efficacy among Nursing Students. Research and Development in Medical Education, 4 (1), 97101. Doi: $\underline{10.15171 / \mathrm{rdme} .2015 .016}$

Hassel, S., \& Ridout, N. (2018). An Investigation of First-Year Students' and Lecturers' Expectations of University Education. Frontiers in Psychology, https://doi.org/10.3389/fpsyg.2017.02218

Henker, R., Prak, M., \& Koy, V. (2015). Development and Implementation of Cornerstone Documents to Support Nursing Practice in Cambodia, The Online Journal of Issues in Nursing, 20(2). Doi: 10.3912/OJIN.Vol20No02Man0 
Huston, C., Phillips, B., Jeffries, P., Todero, C., Rich, J., Knecht, P., ... \& Lewis, M. P. (2018). The academic-practice gap: Strategies for an enduring problem. Nursing Forum, 53 (1), 27-34.

Institute of Medicine. (2000). To err is human: Building a safer health system. Washington, DC: National Academy Press

Jeong, I., Kawther,H., Koichiro,O., Nila, R., \& Yihao, D. (2018). Influential factors of student evaluations of teaching in a nursing program. Teaching and Learning in Nursing, 13, 86-94. https://doi.org/10.1016/.j.teln.2018.01.002

Kermansaravi, F., Navidian, A., \& Yaghoubinia,F. (2015). Nursing Students' Views of Nursing Education Quality: A Qualitative Study. Global Journal of Health Science, 7 (2), 351-359. doi: 10.5539/gihs.v7n2p351

Koto-Shimada, K., Yanagisawa, S., Boonyanurak, P., \& Fujita, N. (2016) Building the capacity of nursing professionals in Cambodia: Insights from a bridging program for faculty development. International Journal of Nursing Practice; 22 (1), 22-30 Doi:10.1111/ijn.12436

Koy V. (2016). The Lifespan of Nursing Education in Cambodia. Belitung Nursing Journal, 2 (4), 65-69. doi: 10.33546/bnj.27 ISSN: 2477-4073

Koy, V., Yunibhand, J., Angsuroch, Y., \& Turale, S. (2017). Development and Psychometric Testing of the Cambodian Nursing Care Quality Scale. Pacific Rim International Journal of Nursing Research, 21(4). https://he02.tcithaijo.org/index.php/PRIJNR/article/view/88918

Krosnick, J. (1991). Response Strategies for Coping with the Cognitive Demands of Attitude Measures in Surveys. Applied Cognitive Psychology, 5(3), 213-36. https://doi.org/10.1002/acp.2350050305

Long, C., Ibrahim, Z., \& Kowang, T. (2014). An Analysis on the Relationship between Lecturers' Competencies and Students' Satisfaction. International Education Studies, $7(1), 37-46$. 
Nur, F., Taib, J., \& Jamil, H. (2014). Comparative Study on Course Evaluation Process: Students' and Lecturers' Perceptions. Procedia - Social and Behavioral Sciences, 3, 380-388. doi: 10.1016/J.SBSPRO.2014.01.1436

Odetola, T., Oluwasola, O., Pimmer, C., Dipeolu, I., Akande, S., Olaleye, O., ... \& Ajuwon, A. (2018). Theory-practice gap: The experiences of Nigerian nursing students. Africa Journal of Nursing and Midwifery, 20 (1), 1-13.

Rejali, M., Mostajeran, M., \& Lotfi, M. (2010). Health students' attitudes towards their field of study and future career in health faculty of Isfahan University of Medical Sciences. Health System Research, 6 (1), 106-115.

Salifu, D., Gross, J., Salifu, M., \& Ninnoni, J. (2019). Experiences and perceptions of the theory-practice gap in nursing in a resource-constrained setting: A qualitative description study. Nursing Open, 6 (1), 72-83.

Sanaei Nasab, H., Rashidy Jaha, H., Tavakoli, R., Delavari,A., \& Rafati, H. (2010). Amount of health-treatment services management bachelor students' satisfaction from their educational field. Educational Strategies in Med Science, 3 (1), 5-6.

Theam, R., (2015). Public Service Culture in Cambodia: Impacts on the Delivery of Core Public Services. Unpublished Thesis

Walker, L. (2016). A Bridge to Success: A Nursing Student Success Strategies Improvement Course. Journal of Nursing Education, 55 (8), 450-453. https://doi.org/10.3928/01484834-20160715-05

WHO Western Pacific Region Nursing and Midwifery Databank, Cambodia http://www.wpro.who.int/hrh/about/nursing midwifery/db cambodia 2013.pdf

Yang, Z., Becerik-Gerber, B., \& Mino, L. (2013). A study on student perceptions of higher education classrooms: Impact of classroom attributes on student satisfaction and performance. Building and Environment, 70, 171-188. https://www.sciencedirect.com/science/article/abs/pii/S0360132313002564 
Yin, H., Lu, G., \& Wang, W. (2014). Unmasking the teaching quality of higher education: students' course experience and approaches to learning in China. Assessment \& Evaluation in Higher Education, 39 (8), 949970. doi: $\underline{10.1080 / 02602938.2014 .880107}$

Young, K., Joines, J., Standish, T., \& Gallegher, V. (2019). Student evaluations of teaching: the impact of faculty procedures on response rates. Assessment \& Evaluation in Higher Education, 44 (1), 37-49. doi.org/10.1080/02602938.2018.1467878

Zerihun, Z., Beishuizen, J., \& Van Os, W. (2012). Student learning experience as indicator of teaching quality. Education Assessment and Evaluation Accountability, 24, 99-111. Doi 10.1007/s11092-011-9140

Zieber, M., \& Williams, B. (2015). The experience of nursing students' who make mistakes in clinical. International Journal of Nursing. Education and Scholarship, 12 (1), 1-9. 